\title{
Teacher's Understanding of the Scientific Approach in the 2013 Curriculum for Early Childhood Education
}

\author{
Rohita $^{1 凶}$, Nila Fitria ${ }^{2}$, Radhiya Bustan $^{3}$, Dody Haryadi $^{4}$ \\ Universitas Al Azhar Jakarta Indonesia
}

\begin{abstract}
The purpose of this study was to determine the teacher's understanding of the scientific approach in the 2013 PAUD curriculum. The method used is a survey with data collection techniques using a questionnaire. Respondents were 100 teachers from 100 TK in 5 DKI Jakarta regions. The conclusion of this study is that the understanding of the kindergarten teacher about the 2013 curriculum of PAUD is in the category of meaningful interpreting not only the transfer of meaning from one language into another language but also from an abstract conception to become a model, namely a symbolic model to make it easier for people to learn, in terms it is easy to learn concept of the scientific approach which includes 5 scientific steps, namely observing, asking, gsthering information, reasoning, and communocating, so that it will be easy to learn and apply in the learning process which is characterized by $61 \%$ of respondents able to explain the scientific approach, and $7.14 \%$ of respondents able describe the scientific approach to RPPH correctly.
\end{abstract}

Keywords: scientific approach, 2013 curriculum, kindergarten teacher

\begin{abstract}
Abstrak
Tujuan dari penelitian ini adalah untuk mengetahui pemahaman guru tentang pendekatan saintifik dalam kurikulum 2013 PAUD. Metode yang digunakan adalah survey dengan teknik pengumpulan data menggunakan pedoman wawancara. Responden adalah 100 guru dari 100 TK di 5 wilayah DKI Jakarta. Kesimpulan penelitian ini adalah pemahaman guru TK tentang kurikulum 2013 PAUD berada pada kategori pemahaman menerjemahkan yang bermakna bukan hanya pengalihan (translation) arti dari bahasa yang satu ke dalam bahasa yang lain tetapi juga dari konsepsi abstrak menjadi suatu model, yaitu model simbolik untuk mempermudah orang mempelajarinya, dalam hal ini mudah mempelajari konsep pendekatan saintifik yang meliputi 5 langkah saintifik, yaitu mengamati, menanya, mengumpulkan informasi, menalar, dan mengkomunikasikan, sehingga akan mudah pula untuk dipelajari dan diterapkan dalam proses pembelajaran yang ditandai dengan $61 \%$ responden mampu menjelaskan pendekatan saintifik, dan $7.14 \%$ responden mampu menjabarkan pendekatan saintifik pada RPPH dengan benar.
\end{abstract}

Kata kunci: pendekatan saintifik, kurikulum 2013, guru taman kanak-kanak

@ Jurnal Obsesi Prodi PG-PAUD FIP UPTT 2018

$\triangle$ Corresponding author :

Address : Jakarta, Indonesia

ISSN 2356-1327 (Media Cetak)

Email : rohita@uai.ac.id

ISSN 2549-8959 (Media Online) 


\section{INTRODUCTION}

A teacher, as one of the responsible parties towards a child's educationparticularly a child of age 4-6 years old, has to pay attention to what kind of educational stimulation she or he will give to a child. One of the things that should be paid attention to is the daily lesson plan which contains various of activities, methods, media and the assessment tool which will be used in one day of learning at school. The daily lesson plan is the guide for the teacher as to what she or he will give to the early child and also how to give it to increase the child's ability according to his or her aspect and level of development.

The daily lesson plan is one of the documents in the education unit level curriculum of the early childhood education programs, namely the daily lesson plan is included in the second document which contains the semester program plan, the weekly lesson plan and the daily lesson plan. The daily lesson plan is arranged as the guide for daily lesson which components are: the theme/ sub-theme/ sub -sub-theme, the age group, the time allocation, learning activities (the opening, the main and the closing activity), the indicators of developmental achievement, the assessment of a child's development, and media and learning sources. All of these components are regulated in the curriculum (The Ministry of Education and Culture of The Republic of Indonesia). That is why the making of the daily lesson plan should be in accordance with the curriculum, particularly the applicable curriculum, namely the 2013 curriculum of the early childhood education programs. One of the characteristics of the 2013 curriculum of the early childhood education programs is the application of the scientific approach in the learning process. The scientific approach is an approach in which the learning process given to the children is carried out using the scientific steps which consisting of observing, asking, collecting information, associating and communicating. These scientific steps should be planned by the teacher before applying them with the children and included in the daily lesson plan. Planning the scientific steps requires not only the teacher's knowledge of the scientific approach, but also her or his understanding about it so that the teacher can apply the approach to the learning plan and carry out the learning process for kindergarten age groupaccordingly. Based on these, this study is conducted with the purpose of determining the understanding of kindergarten teachers of the scientificapproach in the 2013 curriculum of the early childhood education programs.

In the book written by Sudijono (2011: 50), it is stated that the meaning of understanding is the ability to understand or comprehend something after that thing is known and remembered. Understanding is deeper than knowledge. It means that to be able to understand something, it requires background knowledge. Therefore, it is impossible for one to understand the 2013 curriculum of the early childhood education programs, if one doesn't have the background knowledge of it. Understanding, according to Daryanto (2008: 106), is divided into three categories, namely: 1). Translation which doesn't only mean transfer of meaning from one language to another, but also from abstact conception to a symbolic model to make it easier to learn, 2). Interpretation, which means the ability to recognize and understand which can be done by connecting the knowledge obtained before with the one after, connecting between chart with the actual condition described, and distinguishing the main subject from the secondary one, and 3). Extrapolation, namely the ability to foresee consequences or expand perception in the sense of time, dimension, case or problem.

In relation to the study conducted, the purpose of which is to determine teachers's understanding of the scientificapproach, it can be said that a teacher should have a good understanding of various things related to what she or he will teach the students, in particular the understanding of the scientific approach. 
A teacher is a professional staff. In the Act of the Republic of Indonesia No. 14 of 2005 concerning teachers and college professors, it is stated that a teacher as a professional staff means that, as teaching can only be done by a person who is academically qualified, competent and certified to teach in accordance with the requirements for each particular type and level of education (the Ministry of Education and Culture of the Republic of Indonesia, 2012). The competencies required for teachers, in this case teachers of the early childhood education programs, include pedagogical, personal, social and professional competencies (the Ministry of Education and Culture of the Republic of Indonesia, 2014). In relation to the study conducted, the required competency is the pedagogical competency. The pedagogical competency is the ability to manage the learning process of the students. One of the required indicators is planning developmental activities for early childhood in accordance with the curriculum. As for the required sub-competencies, they are as follows: 1. Making developmental programs for early childhood according to the children's theme and needs in the various aspects of delevopment, and 2 . Making plan of play activities in the form of annual, semi-annually,weekly and daily program (the Ministry of Education and Culture of the Republic of Indonesia, 2014). In accordance with the indicators of the pedagogical competency, it is safe to say that a teacher should have a good understanding of the 2013 curriculum of the early childhood education programs in order to manage the learning process which is started by making plan of play activities.

In accordance with the Act of the Republic of Indonesia No. 20 of 2003 concerning the National Education System Article 1 point 19, curriculummeans a set of plans and regulations about the aims, content and material of lessons and the method employed as the guidelines for the implementation of learning activities to achieve given education objectives (the Act of the Republic of Indonesia No. 20 of 2003, 2003). The curriculum of the early childhood programs used today is the 2013 curriculum of the early childhood education programs. Prihadi said that the implementation of this curriculum is characterized by a fundamental change in the learning process which is focusing on active learning. By way of the 2013 curriculum, teachers are expected to make the children participate more actively by using their five senses which supported with suitable media and learning method (Prihadi, 2014). Therefore, the success of the implementation of the 2013 curriculum depends on teachers's understanding of the curriculum and her or his ability to expandthe learning process according to the active learning approach. One of the learning approaches used in the 2013 curriculum is the integrated thematical approach. This approach is done in the opening, main and closing of the activity level (the Ministry of Education and Culture of the Republic of Indonesia, 2015). The opening activity is carried out to prepare the children psychologically and physically to take part in the learning process. This activity is related to the discussion of the sub-theme or the sub-sub-themethat is going to be implemented at the time.

The main activity is an attempt to make a play activity which gives the children a direct learning experiment as a foundation to build attitude and acquire knowledge and skill. The main activity is carried out with the scientific approach including observing, asking, collecting information, reasoning and communicating. In relation to the scientific approach in the Regulation of the Minister of Education and Culture of the Republic of Indonesia No. $81 \mathrm{~A}$ of 2013 concerning the Implementation of Curriculum, in the section General Guidelines of Learning, Appendix IV,it is stated that learning process consists of five principal learning experiences, namely observing, asking, collecting information, associating and communicating (the Ministry of Education and Culture of the Republic of Indonesia, 2013). 
Observing is an activity conducted in order toknow an objectusing the senses, such as seeing, hearing, smelling, touching and tasting. Asking is an activity conducted in order to find out about an object observed or other things one wants to know about. Collecting information is conducted by way of giving children a chance to do, try, discuss and conclude results from various sources. Reasoningis the ability to connect the already obtained information with the new one in order to a better understanding about something. And communicating is delivering the things which already learned in various forms, such as telling stories, showing motions and art projects.

These five activities called the scientific approach should be carried out by the children in a day of the learning process. This is because children not only need to be given a chance to observe various things, but also a chance to ask, collect information, reason and communicate what they get through different activities. Furthermore, the closing activity is a relaxing activity which can be done in the form of making simple conclusion of the activities which have been carried out, such as the moral, good advices, etc.

However, in relation to the implementation of the scientific approach, Prihadi, in the paper he presented in In House Training, stated that the weakness occurs in the central part of the learning process (Prihadi, 2014)in which the implementation of the scientific approach is mostly executed. Another studyresult about the implementation of the scientific approach conducted by PratiwiAyu, Lestarih, Usman Mulbar and Asdar titledThe Implementation of The Scientific Approach in The Achievement of Mathematic Competency in the Thematic Learning in the Fifth Grade Students of the Presidential Instruction Primary SchoolKarunrung Makassar. The result is divided into 3 parts, namely the planning stage, the implementation stage and the assessment stage. In the planning stage, the teachers only planned 3 out of 5 scientific activities, namely observing, collecting information and communicating.
In the implementation stage, all the five scientific activities were carried out. The students implemented the thematic learning of the scientific approach by way of observing things using an LCD or their textbooks. Meanwhile, in the question and answer session, the questions asked by the students were still about the materials presented by the teachers, anddid not reach the level of factual questions or hypothetical ones. In the part of collecting information, the information collected by the students were limited to the information from students's textbooks, and they did not submit any information besides. Therefore, the information collected did not increase their knowledge. And in the reasoning part, the students proceeded the information solely by way of answering questions given by the teachers to every student group. Furthermore, in the communicating part, the teachers are considered successful because every student presented the observation result bravely and confidently.

In addition to the group activities, the teachers only implemented 2 out of 5 activities of the scientific approach in the assessment stage, namely collecting information ad communicating. Based on the study result, it was found that the teachers still did not havea good planning ability of the implementation of the scientific approach that they planned only 3 out of 5 scientific activities, and assessed only 2 out of 3 planned scientific activities. Nevertheless, the teachers did carry out all the 5 scientific activities in the learning process. However, it was for certain contrary to what was planned beforehand (Lestarih, Mulbar\&Asdar, 2015).

However, it is still important to implement the scientific approach. The studyresult by Ni Wyn. Meliawati, Md. Suarjana and Uh Pt PutriniMahadewi titled The Analysis of The Implementation of The Scientific Approach in the Learning Process Based On the $9^{\text {th }}$ Theme of the 2013 Curricululm(My Healthy and Nutritious Food) showed that the scientific approach in the learning process based on the 2013 curriculum was successfully implemented in the primary shool as the study subject. 
The data showed that the teaching ability of the $4^{\text {th }}$ grade teachers of the Primary School No.4 Banyusari is at $90.41 \%$ which means that the teacher carried out the learning process with great effectivity. Meanwhile, the data from the students showed that the learning process using the scientific approach is quite effective, namely at $71.77 \%$, but there was constraint in adjusting the materials with the time allotment.Another study showing the importance of the implementation of the scientific approach is the study by Nur Alamsyah titledThe Implementation of The Scientific Approach to Improve TheStudents's Creativity and Learning Outcome in the Science Subject which showed that the students's activity in the learning process was categorized 'effective'. The result showed that $100 \%$ of the students were creative; the learning outcome indicated that the average cognitive score of the students was 84 , the average attitude score was 88 , and the average psychomotor score was 81 with the mastery category. And the individual mastery reached $92 \%$ with the mastery category. In addition to that, the students's respond reached the 'positive' level or in the category of 'happy, new, interesting and yes'.Based on the aforementioned data, the study concluded that the scientific approach can improve the students's creativity and learning outcome (Alamsyah, 2016)

\section{METHOD}

The method used in this studyis qualitative descriptive with questionnaire as the data collection method. And in order to support the information collected, documentary analysis is done, namely the analysis of the dailylesson plan. The study was conducted in 5 areas ofthe special capital region of Jakarta with total respondents 100 teachers from 100 kindergartens. The respondents were assigned by way of sampling, namely taking one sub-district in each area ofthe special capital region of Jakarta, and then assigning 20 kindergartens in each subdistrict.
A qualitative descriptive method was used to analyze the collected data in order to determine the kindergartenteachers's understanding of the scientificapproach with two indicators i.e. the ability to explain the scientific approach and the abilty to describethe scientific approach in the daily lesson plan. The analyzed data is presented in the form of chart, table and narration to portray the study result.

\section{RESULT AND DISCUSSION}

\section{The Study Result \\ The Ability to Explain The Scientific Approach}

The data on the ability to explain the scientific approach was obtained fromthe questionnaire given to 100 kindergarten teachers as respondents, presented in the form of chart as follows:

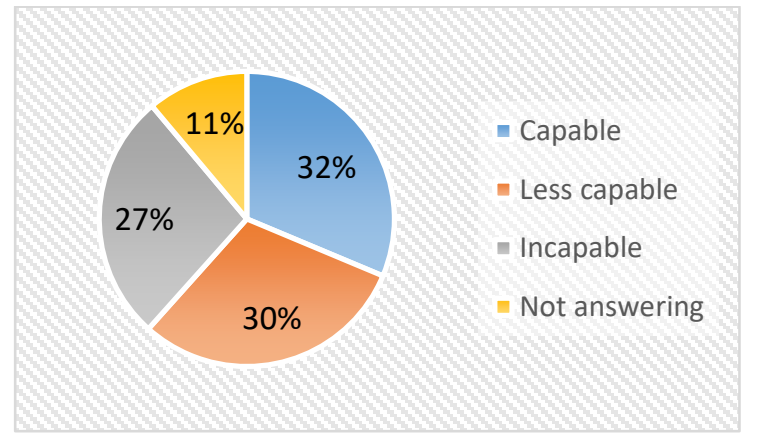

Picture 1: The Data on The Ability to Explain The Scientific Approach

The answers from $31 \%$ of the respondents who were capable to answer correctly the question of what the scientific approach is are as follows: 1. a scientific approach in the learning process, consisting of observing, asking, reasoning, trying and making network for all the subjects; 2. a learning process designed to make children actively go through the stages; 3.a learning process which implementing the children's interest approach so that they participate more actively; 4. alearning approach which focusing on direct experiences; 5. an approach designed to make children actively construct concepts through stages; and 6 . the children can make conclusion of their experiences. 
Furthermore, 30\% of the respondents fall into the 'less capable' category with the answers as follows: 1. an approach based on making experiments and the knowledge based on children's reason; 2. a learning method which focusing on practice, the reasoning approachto make the children able to reason themselves; 3 . a scientific approach to make children more active in every learning process; 4. observing learning media; and 5 . a scientific framework by the 2013 curriculum.

Meanwhile, $27 \%$ of the respondents fall into the 'incapale' category answered as follows: 1. a learning system using playing media and tools as a child's approach; 2. a thematic approach; 3. a scientific approach which focusing on children's needs; 4 . an approach with various methods; 5 . a child's approach to the materials taught using teaching media; and 6 . there should be correlation from the beginning of the learning process until the end in a day.

\section{The Abilty to Describe The Scientific Approach in The Daily Lesson Plan}

The scientific approach is an approach used in the 2013 curriculumof the early childhood education programs, the description of which can be seen from its inclusion in the daily lesson plan.

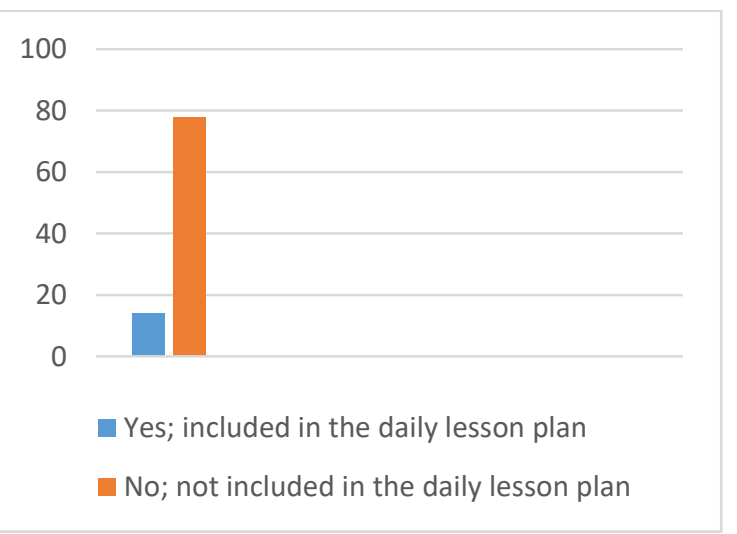

Picture 2: Inclusion of The Scientific Approach in The Daily Lesson Plan

From 92 kindergartens which giving the daily lesson plan, only 14 of them-or about $15.21 \%$-inserted the scientific approach in the daily lesson plan.

\section{Discussion \\ The Ability to Explain The Scientific Approach}

The study result of the ability to explain the scientific approach showed 3 categories of answers, namely 'capable', 'less capable' and 'incapable'. Based on the answers given, the respondents fall into the 'capable' category, if $i$ there were minimum 3 out of 5 scientific stepsin their answers (the answer no.1). By stating 3 out of scientific steps in their answers, the teachers are considered to know that the scientific approach is an approach in the learning process in which the teacher plans the children's activities, i.e. not only do the children observe-which only stimulating two senses, but also are encouraged to ask, collect information, reason and communicate. Another answer falling into this category is when the respondents stated that there were activities planned with the purpose of making the children more actively gain direct experiences-by all means through the scientific stages (the answers no.2 - 6). Therefore, the children eventually can convey what they have learnt and make (simple) conclusion from their experiences.

It is in accordance with the scientific approach in the Regulation of the Minister of Education and Culture of the Republic of Indonesia No. 81A of 2013 concerning the Implementation of Curriculum, in the section General Guidelines of Learning, Appendix IV, it is stated that learning process consists of five principal learning experiences, namely observing, asking, collecting information, associating and communicating called the scientific approach.

Meanwhile, the other respondent group falls into the 'less capable' category in consequence of their incomplete answers. It can be interpreted that the teachers still don't have a good understanding of the scientific approach, or their understanding is limited to only several things. It is portrayed from their answers which only stating 1 or 2 out of 5 scientific steps. 
The teachers only stated that the scientific approach as a learning method which focusing on practice; the reasoning approach to make the children able to reason themselves; observing learning media; and direct observation (the answers no. 2, 3, 5 and 7). Other answers indicated that the teachers only give general explanation, for example a teacher describedthe scientific approach as an approach based on making experiments, and knowledge based on children's reason; a scientific approach to make children more active in every learning process; and a scientific framework by the 2013 curriculum (the answers no. 1, 4, 6).

Moreover, the 'incapable' category can beseen from their general answers, namely the teachers still don't know well about the scientific approach. Among the stated answers falling into this category, it was stated that the scientific approach is a learning system using playing media and tools as a child's approach (the answer no. 1). From the aforementioned answer, it can be said that a learning process for kindergarten age group should duly use playing media and tools.But the problem here is whether or not those are used to encourage children to observe and collect information from the playing media; raise their curiousity; improve their reasoning so that, in the end, they can share the experiences they get using those playing media and tools.

Similarly, the answers no. 2, 4 and 5 stated that the scientific approach is a thematic approach; an approach with various methods and a child's approach to the materials taught using teaching media. Basically, even without the scientific approach, kindergarten teachers should indeed use a thematic approach and various methods in the learning process in kindergarten.
The Table of The Percentage of The Ability to Explain The Scientific Approach

\begin{tabular}{|c|c|}
\hline $\begin{array}{c}\text { The Category of The } \\
\text { Ability }\end{array}$ & Total Respondents \\
\hline Capable & $31 \%$ \\
\hline Less capable & $30 \%$ \\
\hline Incapable & $27 \%$ \\
\hline Not answering & $12 \%$ \\
\hline
\end{tabular}

According to the table, it can be said that $60 \%$ of the kindergarten teachers already know the scientific approach well enough that can be categorized as understandingtranslation. As Daryanto stated (2008: 106), understanding translation is not only the ability to translate a meaning from one language to another, but also a concept from abstract conception to a symbolic model to make it easier to learn.

\section{The Abilty to Describe The Scientific Approach in The Daily Lesson Plan}

In relation to the abilty to describe the scientific approach in the daily lesson plan, only 14 out of 92 respondents inserted the steps of the scientific approach in the daily lesson plan. It can be interpreted that the teachers still don't have a good understanding of the scientific approach so that they are still incapable to insert it in the daily lesson plan.

Meanwhile, there are still differences between the answers of the 14 respondents which inserting the steps of the scientific approach in the daily lesson plan. The differences can be seen from the inclusion of the scientific approach in the daily lesson plan and the fulfillment of activities in the last three columns of the scientific steps, i.e. collecting information, reasoning and communicating. Furthermore, the 5 steps of the scientific approach were correctly implemented only by one respondent, both in fulfilling each step and in putting them in the main activity. This is in accordance to what stated in the Regulation of the Minister of Education and Culture of the Republic of Indonesia No. 146 of 2013 concerningthe early childhood education programs. 
Overall, the description of the scientific approach in the daily lesson plan is presented in the table below:

The Table of The Implementation of The Scientific Approach in The Daily Lesson Plan

\begin{tabular}{|c|c|}
\hline $\begin{array}{c}\text { The Scientific } \\
\text { Approach }\end{array}$ & $\boldsymbol{\Sigma}$ The Respondent \\
\hline Observing & $92.85 \%$ \\
\hline Asking & $100 \%$ \\
\hline Collecting information & $7.14 \%$ \\
\hline Reasoning & $14.28 \%$ \\
\hline Communicating & $7.14 \%$ \\
\hline
\end{tabular}

Based on the information above, it can be said that there are still many kindergarten teachers who don't know what activity they should fulfill in the column of the scientific step, especially in the column 'collecting information', 'reasoning' and 'communicating'. Therefore, in general, it can be said that there is a difficulty in determining suitable activities which correspond to the scientific approach. This can cause an error or incompatibility, particularly in the part of the main activity.

This is in accordance with what stated by Prihadi (2014) that the weakness occurs in the development of the central part of the learning process (Prihadi, 2014) in which the implementation of the scientific approach is mostly executed.Based on the table above, it is clearly seen that only $7.14 \%$ of the respondents inserting the five steps of the scientific approach in the daily lesson plan. It indicates the teachers's inability in describing the scientific approach in the daily lesson plan.

The study by PratiwiAyuLestarih, Usman Mulbar and Asdar titled The Implementation of The Scientific Approach in the Mathematic Competency in the Thematic Learning in the Fifth Grade Students of the Presidential Instruction Primary SchoolKarunrung Makassar also showed a similar result. The result is divided into 3 parts, namely the planning stage, the implementation stage and the assessment stage. In the planning stage, the teachers only planned 3 out of 5 scientific activities, namely observing, collecting information and communicating. In the implementation stage, all the five scientific activities were carried out. The students implemented the thematic learning of the scientific approach by way of observing things using an LCD or their textbooks. Meanwhile, in the question and answer session, the questions asked by the students were still about the materials presented by the teachers, and did not reach the level of factual questions or hypothetical ones. In the part of collecting information, the information collected by the students were limited to the information from students's textbooks, and they did not submit any information besides. Therefore, the information collected did not increase their knowledge. And in the reasoning part, the students proceeded the information solely by way of answering questions given by the teachers to every student group. Furthermore, in the communicating part, the teachers are considered successful because every student presented the observation result bravely and confidently.

In addition to the group activities, the teachers only implemented 2 out of 5 activities of the scientific approach in the assessment stage, namely collecting information ad communicating. Based on the study result, it was found that the teachers still did not have a good planning ability of the implementation of the scientific approach that they planned only 3 out of 5 scientific activities, and assessed only 2 out of 3 planned scientific activities. Nevertheless, the teachers did carry out all the 5 scientific activities in the learning process. However, it was for certain contrary to what was planned beforehand.

Whereas, the success of the implementation of the 2013 curriculum depends on teachers's understanding of the curriculum and her or his ability to expand the learning process according to the active learning approach. Teachers's ability to implement the scientific approach which described in the daily lesson plan can also increase the effectiveness of the learning process and children's learning outcome. It is in accordance with the study by Ni Wyn. Meliawati, Md. Suarjana and $\mathrm{Uh} \mathrm{Pt}$ 
PutriniMahadewi titled The Analysis of The Implementation of The Scientific Approach in the Learning Process Based On the $9^{\text {th }}$ Theme of the 2013 Curricululm (My Healthy and Nutritious Food) which showing that the scientific approach in the learning process based on the 2013 curriculum was successfully implemented in the primary shool as the study subject. The data showed that the teaching ability of the $4^{\text {th }}$ grade teachers of the Primary School No. 4 Banyusari is at $90.41 \%$ which means that the teacher carried out the learning process with great effectivity. Meanwhile, the data from the students showed that the learning process using the scientific approach is quite effective, namely at $71.77 \%$.

Based on the analysis of the abilty to describe the scientific approach in the daily lesson plan, only $7.14 \%$ of the respondest were able to describe it correctly. If the information of the two indicators, namely the ability to explain and the abilty to describethe scientific approach, are combined, it can be said that the kindergarten teachers fall into the first category of understanding, namely the understanding translation. Daryanto (2008: 106) stated that understanding translation is not only the ability to translate a meaning from one language to another, but also a concept from abstract conception to a symbolic model to make it easier to learn.

\section{CONCLUSION}

Based on the two indicatorsi.e. the ability to explain the scientific approach and the abilty to describethe scientific approach in the daily lesson plan, the conclusion of the study is that the kindergarten teachers's ability falls into the first category, namelyunderstanding translation which means not only the ability to translate a meaning from one language to another, but also a concept from abstract conception to a symbolic model to make it easier to learn the five steps of the scientific approach i.e. observing, asking, collecting information, reasoning and communicating. Thus, it is easier to learn and apply in the learning process.However, the teachers still need to improve their ability in describing the scientific approach in the daily lesson plan correctly.

\section{ACKNOWLEDGMENT}

Thank you very much for: 1) DRPM Directorate General of Strengthening for Research and DevelopmentMinistry of Research, Technology and Higher Education of the Republic of Indonesia for the grant funds given to the researchers in the scheme of University Leading Applied Research (PTUPT), 2) Research and Community Service Institute (LP2M) of University of Al Azhar Indonesia for all the support and facilities given in an effort tocarry out the PTUPT.

\section{REFERENCES}

Alamsyah, N. (2016). Penerapan Pendekatan Saintifik untuk Meningkatkan Kreativitas dan Hasil Belajar Siswa dalam Mata Pelajaran IPA. Jurnal Pendidikan, 1(1), 8188.

Daryanto. (2008). Evaluasi pendidikan. Jakarta: Rineka Cipta

Kementerian Pendidikan dan Kebudayaan. (2014). Peraturan Menteri Pendidikan dan Kebudayan Nomor 137 Tahun 2014 tentang Standar Pendidikan Anak Usia Dini.

Kementerian Pendidikan dan Kebudayaan Republik. (2013). Peraturan Menteri Pendidikan dan Kebudayaan Nomor 81A Tahun 2013 tentang Implementasi Kurikulum.

Kementerian Pendidikan dan Kebudayaan

Republik Indonesia. (2012).

Undang-Undang Nomor 14 Tahun 2005 tentang Guru dan Dosen. https://doi.org/10.1016/j.aquaculture .2007 .03 .021

Kementerian Pendidikan dan Kebudayaan Republik Indonesia. (2015). Menteri Pendidikan Dan Kebudayaan Republik Indonesia Nomor 146 Tahun 2014 Tentang Kurikulum 2013 Pendidikan Anak Usia Dini.

Lestarih, P. A., Mulbar, U., \& Asdar. (2015). Penerapan Pendekatan Saintifik Dalam Pencapaian 
246 | Teacher's Understanding of the Scientific Approach in the 2013 Curriculum

Kompetensi Matematika Dalam

Pembelajaran Tematik Di Kelas V

Sd Inpres Karunrung Makassar, 3(3), 308-327.

Meliawati, N. W., Pt, L., \& Mahadewi, P. (2015). Analisis Penerapan Pendekatan Saintifik Terhadap Dalam Pembelajaran Berdasarkan Kurikulum $2013 \quad$ Universitas Pendidikan Ganesha e-Journal PGSD Universitas Pendidikan Ganesha, 9(4).

Nana Sudjana. (1992). Penilaian Hasil Proses Belajar Mengajar. Bandung: PT. Remaja Rosdakarya

Prihadi, B. (2014). Penerapan langkahLangkah Pembelajaran dengan Pendekatan Saintifik dalam Kurikulum 2013, 1-8. Retrieved from http://staffnew.uny.ac.id/upload/131 662618/pengabdian/penerapanpendekatan-saintifik.pdf

Sudijono, Anas. (2011). Pengantar Evaluasi Pendidikan. Jakarta: Rajawali Pers

UU Nomor 20 Tahun 2003. (2003). Sistem pendidikan nasional. Jakarta: Direktorat Pendidikan Menengah Umum.

https://doi.org/10.1016/j.ypmed.200 8.01 .025 